\title{
The affinity of mangrove species using Association and Cluster Index in North Coast of Jakarta and Segara Anakan of Cilacap, Indonesia
}

\author{
ENDANG HILMI ${ }^{1,2, \bullet}$, LILIK KARTIKA SARI $^{1}$, TRI NUR CAHYO ${ }^{3}$, MUSLIH $^{1}$, ARIF MAHDIANA ${ }^{1}$, \\ SESILIA RANI SAMUDRA ${ }^{1}$ \\ ${ }^{1}$ Program of Aquatic Resources Management, Faculty of Fisheries and Marine Sciences, Universitas Jenderal Soedirman. Jl. Dr. Soeparno, Purwokerto \\ Utara, Banyumas 53122, Central Java, Indonesia. Tel./fax.: +62-281-642360, "email: dr.endanghilmi@gmail.com \\ ${ }^{2}$ Aquatic Resources Graduate Program, Faculty of Fisheries and Marine Sciences, Universitas Jenderal Soedirman. Jl. Dr. Soeparno, Purwokerto Utara, \\ Banyumas 53122, Central Java, Indonesia \\ ${ }^{3}$ Program of Marine Science, Faculty of Fisheries and Marine Sciences, Universitas Jenderal Soedirman. Jl. Dr. Soeparno, Purwokerto Utara, Banyumas \\ 53122, Central Java, Indonesia
}

Manuscript received: 31 May 2021. Revision accepted: 25 June 2021

\begin{abstract}
Hilmi E, Sari LK, Cahyo TN, Muslih, Mahdiana A, Samudra SR. 2021. The affinity of mangrove species using Association and Cluster Index in North Coast of Jakarta and Segara Anakan of Cilacap, Indonesia. Biodiversitas 22: 2907-2918. The affinity of mangrove species using association and cluster index describe relationship among mangrove species. The species association and clustering explain the degree of utilization of resources and space by mangrove species. The association and cluster also describe specific species adaptation in mangrove ecosystems. This paper was aimed to analyze species affinity using association and clustering index of mangrove species. The association index used Chi-square equation and the clustered index used Euclidian distance analysis. The results showed that (i) mangrove density in Segara Anakan (166-4000 trees ha-1) > North Jakarta (220-1100 trees ha $\left.{ }^{-1}\right)$. (ii) Nypa fruticans, Avicennia marina, Rhizophora stylosa and Rhizophora apiculata dominated in Segara Anakan of Cilacap, and Rhizophora stylosa and Avicennia marina dominated in North Jakarta (iii) The association index had 12 pairs of negative species association and 17 pairs of positive species association, but most of mangrove vegetations had no association. (iv) mangrove ecosystem in Segara Anakan and North Jakarta had four clusters with Euclidean distance (ED score) 484 to describe cluster between Bruguiera parviflora-Bruguiera sexangula until 76430847 to describe cluster among Bruguiera gymnorrhiza, Bruguiera parviflora, Ceriops decandra, Exoecaria agallocha, Nypa fruticans, Ceriops tagal, Rhizophora stylosa, and Sonneratia caseolaris
\end{abstract}

Keywords: Mangrove association, mangrove clustering, mangrove density, , North Coast of Jakarta Segara Anakan Lagoon

\section{INTRODUCTION}

The affinity of mangrove species explains the relation of mangrove species to use resources and space in mangrove habitat (Ludwig and Renold, 1988). The species affinity can be described by many indexes including the species association and cluster. Mangrove clustering and association describe the relation and adaptation models of ecosystems using similarity, distance and specific correlation among species (Hilmi et al. 2015; Ludwig and Renold, 1988). The concepts are developed by a dissimilarity pointer known as the Euclidian distance index (Ludwig and Renold, 1988). Essentially, cluster analysis employs hierarchical and non-hierarchical methods (Ludwig and Renold 1988). Meanwhile, mangrove association provides an assessment tool to species relationships (coefficient variation) between various species. The phenomenon also demonstrates the importance of inter-species correlation and further underscores the ability to combine robust or vulnerable bonds (Ludwig and Renold, 1988). These relationships are introduced to aid structural development (Joshi and Bhatt 2015). Chi-Square index calculates the potential mutual existence of species $(\mathrm{E}(\mathrm{a}))$ and is compared by the number plot where the species are discovered (Ludwig and Renold, 1988; Macintosh et al.
2002; Rougier et al. 2005). Furthermore, species relationship mangroves (using associations and clusters index) are essential for effective mangrove forest management (Pham et al. 2019), and are also used to analyze potentials of plant density and species distribution (Ludwig and Renold, 1988), where homogeneity or similarity in ecosystems exist (Cochard et al. 2008).

The affinity of mangrove species (using association and cluster indexes) are analyzed to describe specific relationships among major species, minor species, and association species like Avicennia alba, A. marina, Sonneratia alba, S. caseolaris, Rhizophora apiculata, $R$. mucronata, Rhizophora stylosa, Bruguiera gymnorrhiza, $B$. sexangula, B parviflora, Nypa fruticans, Ceriops decandra, Ceriops tagal, Acrosticum corniculatum, Heritiera littoralis, Exocecaria agallocha and Xylocarpus granatum. The specific of mangrove species relationships showing an adaptation pattern of mangrove species which are largely influenced by sea tide, water inundation and salinity, soil texture, marine pollution, garbage and social activities (Hilmi et al. 2015, 2017; Sari et al. 2016;). Generally, the environmental factors contribute to the cluster pattern, species distribution and correlation (Hilmi et al. 2019; Owuor et al. 2019; Leng and Cao 2020). The cluster and association will develop specific structure of mangrove ecosystem 
(Leng and Cao 2020), specific growth and productivity (Njana 2020), functional model of mangrove structure (Njana 2020), environment adaptation (Leng and Cao 2020), degradation and potential of biodiversity (Owuor et al. 2019), organism habitat (Owuor et al. 2019), potential of above and below-ground biomass, canopy covering, crown leaf spread and tree density (Dencer-Brown et al. 2020).

The mangrove species affinity in Segara Anakan of Cilacap and North Coast of Jakarta are developed to explain the potency of mangrove density, mangrove clusters and mangrove association. The mangrove density, clustering and association provide the zoning base for the density, species distribution and environment characteristics. The specific relationship and mangrove species adaptation reflect the ability of mangrove ecosystem to reduce impact of sea tide, water inundation, and salinity. The purpose of this paper was to analyze species affinity based on mangrove clustering and association in an ecosystem using density, species distribution, and environment characteristics.

\section{MATERIALS AND METHODS}

\section{Research site}

This research was conducted in Segara Anakan Lagoon (West and East) as well as in the mangrove ecosystem of
Nort Coast of Jakarta. In addition, the location is characterized by the mangrove, terrestrial, estuary ecosystems and also by certain rivers, including Donan, Sapuregel, Kembang Kuning, Citanduy, Cimeneng and Cikonde (Hilmi et al. 2017; Hilmi et al. 2019). The Segara Anakan mangrove environment comprises two locations, including Segara Anakan (West and East). These regions are dominated by Avicennia alba, A. marina, Sonneratia alba, S. caseolaris, Rhizophora apiculata, R. mucronata, $B$. gymorrhiza, B. sexangula, $B$ parviflora, Nypa frutican, Ceriops decandra, Ceriops tagal, Acrosticum cornicultum, Heritiera littolaris, Exocecaria agallocha and Xylocarpus granatum (Hilmi, et al. 2017; Hilmi 2018; Hilmi, Sari, and Amron 2020). Meanwhile, the North Coast of Jakarta consists of Muara Angke Wildlife Reserve (SMMA), Angke Kapuk Nature Park (TWA) and Kapuk AngkeKapuk forest. Conservation (HLAK) and Muara Angke Wildlife Reserve (SMMA) (Hilmi, et al. 2017) are occupied by Rhizophora stylosa, Rhizophora apiculata, and Avicennia marina (Hilmi et al. 2017). East Segara Anakan is occupied by 22 stations, while the West is home to 20 research units. Meanwhile, Jakarta's North Coast is influenced by Angke and Ciliwung waters and Java sea (Hilmi et al. 2017). Furthermore, the present study focuses on mangrove clustering in Angke Kapuk, and is categorized into 6 stations (Figure 1 and Table 1).
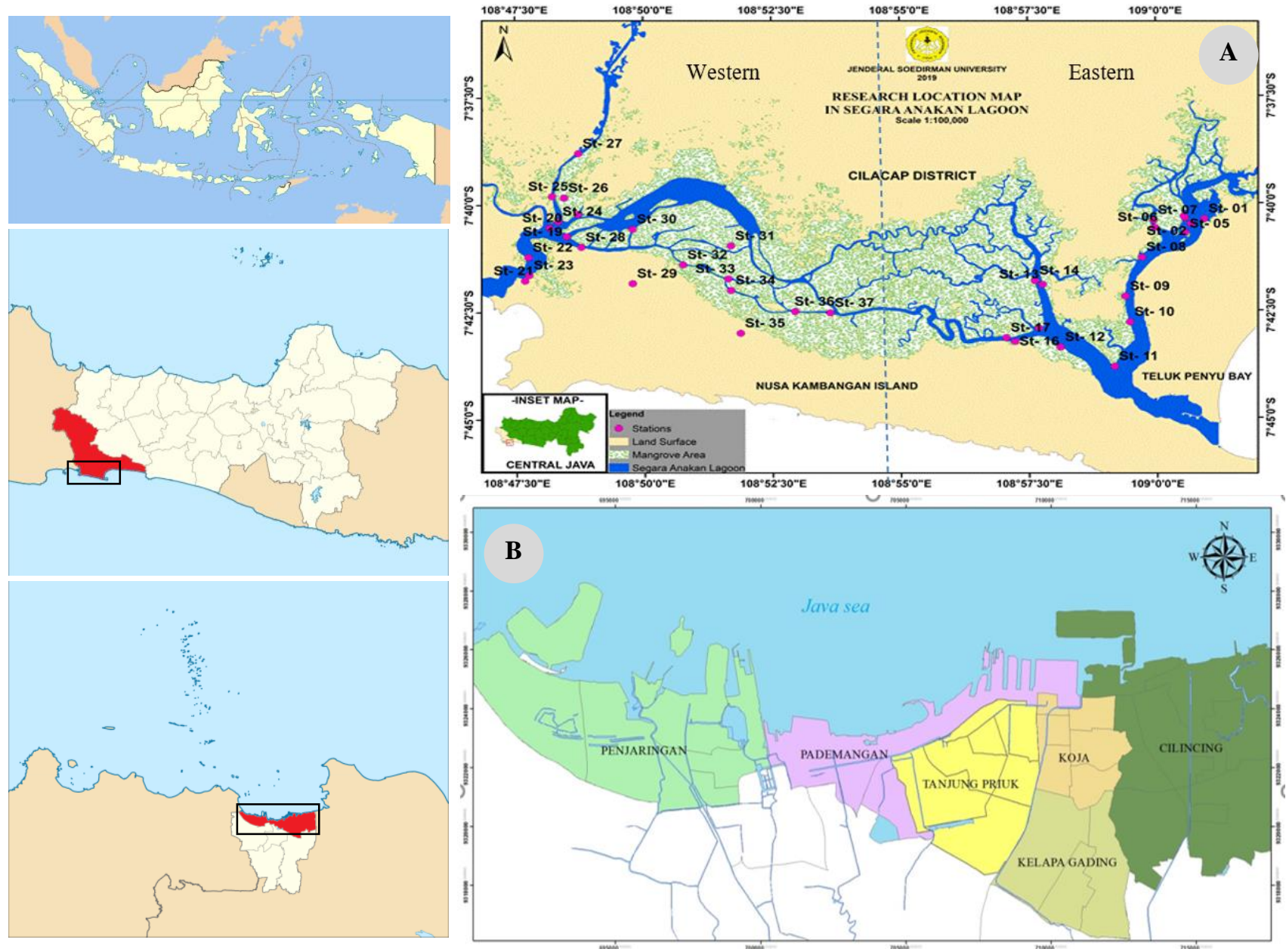

Figure 1. Research area in: A. Segara Anakan of Cilacap, Cilacap, and B. North Coast of Jakarta, Indonesia. Note: $\bigcirc$ : Station 
Table 1. Research stations

\begin{tabular}{|c|c|c|}
\hline \multirow{2}{*}{ Stations } & \multicolumn{2}{|c|}{ Coordinate } \\
\hline & Latitude (S) & Longitude (E) \\
\hline \multicolumn{3}{|l|}{ West Segara Anakan, Cilacap } \\
\hline Sungai Ujung Gagak & $07^{\circ} 40^{\prime} 13^{\prime \prime}$ & $108^{\circ} 48^{\prime} 43^{\prime \prime}$ \\
\hline Sungai Lorogan & $07^{\circ} 40^{\prime} 44^{\prime \prime}$ & $108^{\circ} 48^{\prime} 30^{\prime \prime}$ \\
\hline Sungai Majingklak & $07^{\circ} 40^{\prime} 32^{\prime \prime}$ & $108^{\circ} 48^{\prime} 1^{\prime \prime}$ \\
\hline Sungai Mauara Cawitali & $07^{\circ} 41^{\prime} 46^{\prime \prime}$ & $108^{\circ} 47^{\prime} 41^{\prime \prime}$ \\
\hline Sungai Kebuyutan & $07^{\circ} 41^{\prime} 13^{\prime \prime}$ & $108^{\circ} 47^{\prime} 45^{\prime \prime}$ \\
\hline Sungai Batu Macan & $07^{\circ} 41^{\prime} 38^{\prime \prime}$ & $108^{\circ} 47^{\prime} 46^{\prime \prime}$ \\
\hline Sungai Jongor & $07^{\circ} 40^{\prime} 23^{\prime \prime}$ & $108^{\circ} 48^{\prime} 20^{\prime \prime}$ \\
\hline Sungai Muara Legok & $07^{\circ} 39^{\prime} 48^{\prime \prime}$ & $108^{\circ} 48^{\prime} 13^{\prime \prime}$ \\
\hline Sungai Kayu Mati & $07^{\circ} 39^{\prime} 5^{\prime \prime}$ & $108^{\circ} 48^{\prime} 27^{\prime \prime}$ \\
\hline Sungai Langkap & $07^{\circ} 38^{\prime} 48^{\prime \prime}$ & $108^{\circ} 48^{\prime} 44^{\prime \prime}$ \\
\hline Sungai Karang Braja & $07^{\circ} 40^{\prime} 59^{\prime \prime}$ & $108^{\circ} 48^{\prime} 47^{\prime \prime}$ \\
\hline Sungai Klaces & $07^{\circ} 41^{\prime} 5^{\prime \prime}$ & $108^{\circ} 49^{\prime} 47^{\prime \prime}$ \\
\hline Sungai Inti Ujung Gagak & $07^{\circ} 40^{\prime} 34^{\prime \prime}$ & $108^{\circ} 49^{\prime} 47^{\prime \prime}$ \\
\hline Sungai Muara Bagian & $07^{\circ} 40^{\prime} 58^{\prime \prime}$ & $108^{\circ} 51^{\prime} 42^{\prime \prime}$ \\
\hline Sungai Muara Masigitsela & $07^{\circ} 41^{\prime} 24^{\prime \prime}$ & $108^{\circ} 50^{\prime} 46^{\prime \prime}$ \\
\hline Sungai Pertigaan Ujung Alang & $07^{\circ} 41^{\prime} 44$ & $108^{\circ} 51^{\prime} 39^{\prime \prime}$ \\
\hline Sungai Ujung Alang & $07^{\circ} 42^{\prime} 0^{\prime \prime}$ & $108^{\circ} 51^{\prime} 42^{\prime \prime}$ \\
\hline Sungai Dermaga Ujung Alang & $07^{\circ} 42^{\prime} 6^{\prime \prime}$ & $108^{\circ} 51^{\prime} 53^{\prime \prime}$ \\
\hline Sungai Kali Semak & $07^{\circ} 42^{\prime} 30^{\prime \prime}$ & $108^{\circ} 52^{\prime} 57^{\prime \prime}$ \\
\hline Sungai Pertigaan Sudiro & $07^{\circ} 42^{\prime} 32^{\prime \prime}$ & $108^{\circ} 53^{\prime} 38^{\prime \prime}$ \\
\hline \multicolumn{3}{|l|}{ East Segara Anakan, Cilacap } \\
\hline Kali Panas 1 & $07^{\circ} 40^{\prime} 22.17^{\prime \prime}$ & $109^{\circ} 0 ’ 56.36^{\prime \prime}$ \\
\hline Kali Panas 2 & $07^{\circ} 40^{\prime} 28.91^{\prime \prime}$ & $109^{\circ} 0{ }^{\prime} 40.57^{\prime \prime}$ \\
\hline Kali Panas 3 & $07^{\circ} 40^{\prime} 20.60 \prime$ & $109^{\circ} 0 ’ 33.62 ”$ \\
\hline Kali Panas 4 & $07^{\circ} 40^{\prime} 18.26^{\prime \prime}$ & $109^{\circ} 0 ’ 32.52^{\prime \prime}$ \\
\hline Kali Panas 5 & $07^{\circ} 40^{\prime} 41.12^{\prime \prime}$ & $109^{\circ} 0 ’ 33.98^{\prime \prime}$ \\
\hline Donan 1 & $07^{\circ} 40^{\prime} 33.98^{\prime \prime}$ & $108^{\circ} 59^{\prime} 58.10^{\prime \prime}$ \\
\hline Donan 2 & $07^{\circ} 40^{\prime} 23.79^{\prime \prime}$ & $108^{\circ} 59^{\prime} 56.90^{\prime \prime}$ \\
\hline Donan 3 & $07^{\circ} 41^{\prime} 15.49^{\prime \prime}$ & $108^{\circ} 59^{\prime} 43.22^{\prime \prime}$ \\
\hline Donan 4 & $07^{\circ} 42^{\prime} 10.17^{\prime \prime}$ & $108^{\circ} 59^{\prime} 23.75^{\prime \prime}$ \\
\hline Donan 5 & $07^{\circ} 42^{\prime} 46.06^{\prime \prime}$ & $108^{\circ} 59^{\prime} 29.10^{\prime \prime}$ \\
\hline Donan 6 (Sleko) & $07^{\circ} 43^{\prime} 48.07^{\prime \prime}$ & $108^{\circ} 59^{\prime} 10.78^{\prime \prime}$ \\
\hline Pelawangan Timur & $07^{\circ} 43^{\prime} 20.95^{\prime \prime}$ & $108^{\circ} 58^{\prime} 07.45^{\prime \prime}$ \\
\hline Sapuregel 1 & $07^{\circ} 41^{\prime} 53.33^{\prime \prime}$ & $108^{\circ} 57^{\prime} 46.71 ”$ \\
\hline Sapuregel 2 & $07^{\circ} 41^{\prime} 47.97^{\prime \prime}$ & $108^{\circ} 57^{\prime} 37.81^{\prime \prime}$ \\
\hline Sapuregel 3 & $07^{\circ} 42^{\prime} 54.20^{\prime \prime}$ & $108^{\circ} 57^{\prime} 42.07^{\prime \prime}$ \\
\hline Kembang Kuning 1 & $07^{\circ} 43^{\prime} 12.88^{\prime \prime}$ & $108^{\circ} 57^{\prime} 14.24 \prime$ \\
\hline Kembang Kuning2 & $07^{\circ} 43^{\prime} 07.52^{\prime \prime}$ & $108^{\circ} 57^{\prime} 03.97^{\prime \prime}$ \\
\hline \multicolumn{3}{|l|}{ North Coast of Jakarta } \\
\hline Ekowisata Mangrove Angke & $06^{\circ} 07^{\prime} 18.88^{\prime \prime}$ & $106^{\circ} 45^{\prime} 18.37^{\prime \prime}$ \\
\hline Hutan Lindung Angke Kapuk & $06^{\circ} 06^{\prime} 15.50^{\prime \prime}$ & $106^{\circ} 45^{\prime} 05.41^{\prime \prime}$ \\
\hline Hutan Lindung Angke Kapuk & $06^{\circ} 06^{\prime} 16.556^{\prime \prime}$ & $106^{\circ} 45^{\prime} 49.608^{\prime \prime}$ \\
\hline Hutan Lindung Angke Kapuk & $06^{\circ} 06^{\prime} 16.614^{\prime \prime}$ & $106^{\circ} 45^{\prime} 49.619^{\prime \prime}$ \\
\hline Arboretum Mangrove & $06^{\circ} 06^{\prime} 41.386^{\prime \prime}$ & $106^{\circ} 43^{\prime} 57.374^{\prime \prime}$ \\
\hline Ekosistem Mangrove Galatama & $06^{\circ} 07^{\prime} 24.733^{\prime \prime}$ & $106^{\circ} 45^{\prime} 16.124^{\prime \prime}$ \\
\hline
\end{tabular}

\section{Research design}

\section{Vegetation sampling}

The vegetation sampling employed the cluster technique with the stratification stage, comprising mangrove density and the river basin. Also, the number of stations involved in the analysis in East (22 stations) and West Segara Anakan (20 stations) and North Jakarta (6 stations) (Table 1).

\section{Mangrove trees density}

Furthermore, the mangrove trees density in Segara Anakan was evaluated, using the vegetation analysis equation (Cooray et al. 2021; Hilmi 2018; Xiong et al. 2003; Xiong et al. 2018):

$$
\text { Mangrove trees density }=\frac{\text { Trees number of mangrove speies }}{\text { area }}
$$

The trees density (diameter $>4 \mathrm{~cm}$ ) adopted the line transect method with a sampling plot of $10 \mathrm{~m} \times 10 \mathrm{~m}$. Table 2 shows the trees density distribution of the plant ecosystem (Hilmi et al. 2020). The data of mangrove density were collected from 10 sampling plots/stations. The potential of mangrove trees density are used to analyze distribution of mangrove density, mangrove association and mangrove cluster

\section{Asociation analysis}

The analysis of mangrove vegetation associations between species using contingency tables and are calculated by calculating the value of Chi-square (Ludwig and Renold, 1988).

$$
\text { Chi-square }=\frac{N(a d-b c)^{2}}{(a+b)(a+c)(c+d)(b+d)}
$$

Where: a: the number of plots containing vegetation species $\mathrm{A}$ and $\mathrm{B}$. $\mathrm{b}$ : the number of plots containing vegetation species A only. c: the number of plots containing vegetation species B only. d: the number of plots not have vegetation species $A$ and $B$. N: The number of plots

$$
E(a)=\frac{(a+b)(a+c)}{N}
$$

If score of $\mathrm{a}>\mathrm{E}$ (a) be defined as positive association,

If score of $a<E$ (a) be defined as negative association

\section{Cluster analysis}

Cluster analysis is built using similarity and dissimilarity analysis through euclidian distance analysis (Ludwig and Renold, 1988). The analysis of mangrove clusters followed mathematical manipulation using excel software and was justified by Premiere software. The cluster analysis followed stages:

Stage 1

$$
E D_{j k}=\sqrt{\sum_{i=1}^{s}(x i j-x i k)^{2}}
$$

Stage 2

$$
D(j, k) h=\alpha_{1} D(j, h)+\alpha_{2} D(k, h)+\beta D(j, k)
$$

\begin{tabular}{l|ccccc} 
Stations & $\mathbf{2}$ & $\mathbf{3}$ & $\mathbf{4}$ & $\mathbf{\cdots}$ & $\mathbf{n}$ \\
\hline 1 & $\mathrm{ED}_{12}$ & $\mathrm{ED}_{13}$ & $\mathrm{ED}_{14}$ & & \\
2 & & $\mathrm{ED}_{23}$ & $\mathrm{ED}_{24}$ & & \\
3 & & & $\mathrm{ED}_{34}$ & & \\
$\mathrm{n}$ & & & $\ldots$ & &
\end{tabular}


Where:

Edjk : Euclidean Distance

i : Species

$\mathrm{X} i j$ : Density in station- $j$

$\mathrm{X} i k$ : Density in station- $k$

D : Distance

$\alpha 1: 0.625$

$\alpha 2: 0.625$

$\beta \quad:-0.25$

\section{Data analysis}

The association analysis was illustrated by data tabulation, covering the assessment scores of Chi-square and relation. However, the cluster analysis employed dendrogram models and density data tabulation (Ludwig and Renold, 1988), as well as further described the grouping pattern in Segara Anakan alongside the density (Hilmi 2018; Hilmi et al. 2019).

\section{RESULTS AND DISCUSSION}

The mangrove trees density

Distribution of mangrove trees density in mangrove stations

The mangrove tree density distribution at several stations on the North Coast of Jakarta and Segara Anakan were presented in Figure 2 and Table 2. The obtained data showed a superior ecosystem in Segara Anakan, both West and East, compared to the North Coast of Jakarta. Furthermore, the potential densities in East and West Segara Anakan as well as in the North Coast of Jakarta, occurred between 166-4000 trees $\mathrm{ha}^{-1}, 133-3000$ trees/ha, and 220-1100 trees ha ${ }^{-1}$, respectively.

The data on Table 2 and Figure 2 and ones from Hilmi et al. (2020) also showed that the potential mangrove tree density divided into (i) East Segara Anakan had 9.1\% (very high), $31.8 \%$ (high), $40.9 \%$ (moderate), and 18,2\% (rare) (ii) West Segara Anakan had 5.6\% (very high),5.6\% (high), $11.1 \%$ (moderate), $61.1 \%$ (rare) and $16.7 \%$ (very rare) and (iii) North Coast of Jakarta had 50\% (rare) and 50\% (very rare). These data can be predicted that ecosystem mangrove on North Coast of Jakarta was degraded and must be rehabilitated. However, mangrove ecosystem in Segara Anakan also was degraded but is undergoing a secondary succession process.

Essentially, the potential density is related to environmental conditions, including physical or chemical, water and soil, sedimentation, anthropology, as well as conversion of mangrove forests (Syakti et al. 2013; Giri et al. 2015; Sari et al. 2016). Basically, mangrove tree density in Segara Anakan, both East and West, and the North Coast of Jakarta, are influenced by various levels of pollution (Hidayati et al. 2011; Syakti et al. 2013), sedimentation (Sari et al. 2016), conversion (Giri et al. 2015; Orchard et al. 2015; Hilmi et al. 2017; Castillo et al. 2017) and minimal waste potential (Hilmi et al. 2017). The ability of mangrove trees to grow and live in Segara Anakan and North Coast of Jakarta need effort adaptation toward environmental conditions. Many research describes natural regeneration of mangrove ecosystems in Segara Anakan as superior and faster than Jakarta (Hilmi et al. 2015, 2017, 2019). Consequently, the Segara Anakan region is also experiencing a secondary succession, where plant growth occurs rapidly.

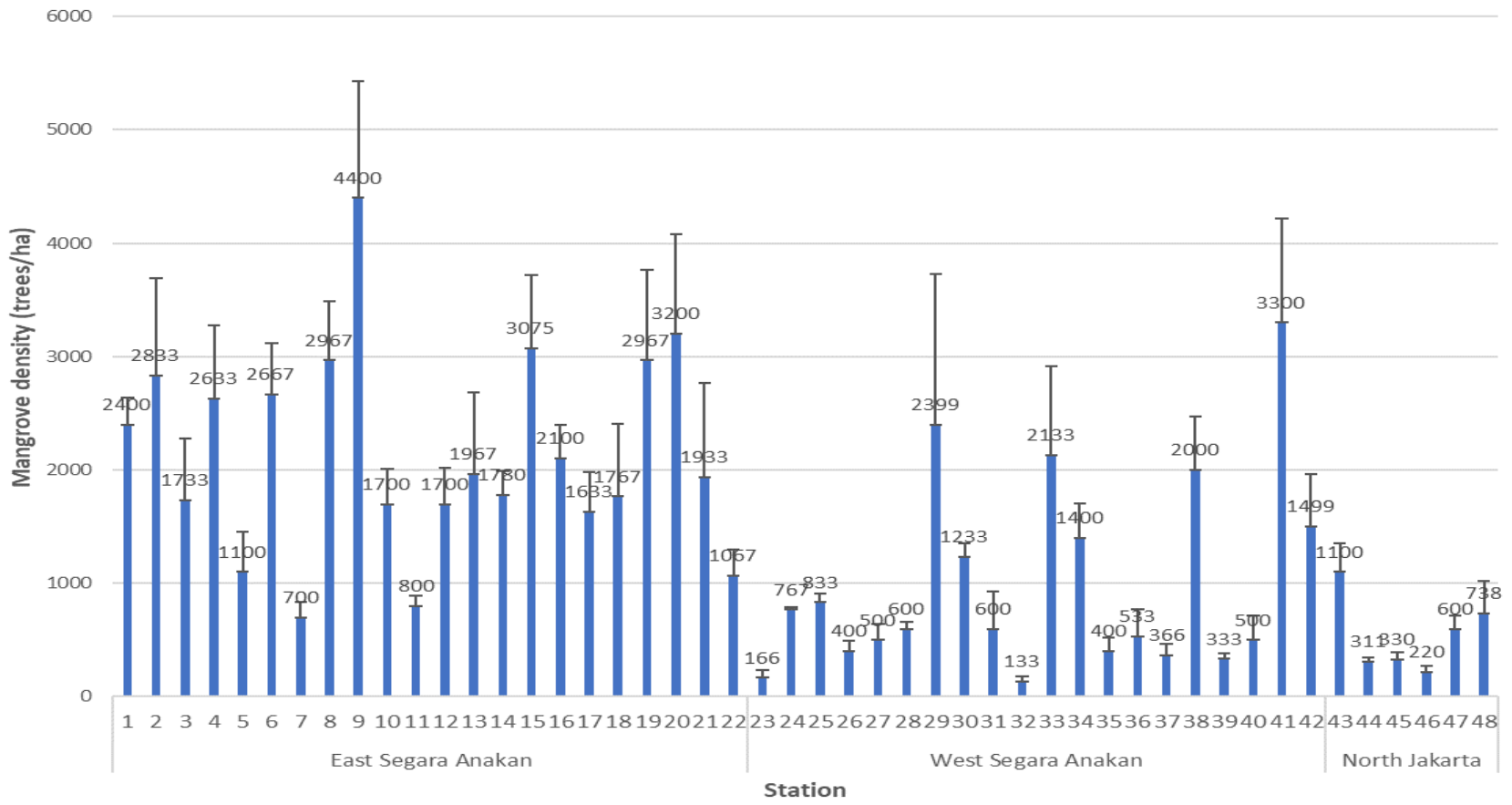

Distribution of mangrove density for each station

Figure 2. Distribution of mangrove density based on mangrove stations 
Table 2. Mangrove density based on distribution of mangrove station

\begin{tabular}{|c|c|c|c|c|c|c|c|c|c|c|c|c|c|c|c|c|c|c|c|c|c|}
\hline \multirow[t]{2}{*}{ Station } & \multicolumn{21}{|c|}{$\begin{array}{c}\text { Mangrove density (trees/ha) } \\
\text { East Segara Anakan (station) }\end{array}$} \\
\hline & 1 & 2 & 3 & 4 & 5 & 6 & 7 & 8 & 9 & 10 & 11 & 12 & 13 & 14 & 15 & 16 & 17 & 18 & $19 \quad 20$ & 21 & 22 \\
\hline Total & 2400 & 02833 & 1733 & 2633 & 1100 & 2667 & 7700 & 2967 & 4400 & 1700 & 800 & 1700 & 1967 & 1780 & 3075 & 2100 & 1633 & 1767 & 29673200 & 1933 & 1067 \\
\hline $\mathrm{Sd}$ & 240 & 858 & 542 & 639 & 353 & 448 & 134 & 522 & 1033 & 306 & 89 & 321 & 717 & 207 & 645 & 300 & 347 & 640 & $\begin{array}{ll}797 & 879\end{array}$ & 835 & 229 \\
\hline Class & High & h High & Moderate & High & Rare & High & Rare & e High & Very 1 & gh Mode & Rare & e Mode & e Mode & Mode & High & Mode & Mode & Mode & High Very 1 & h Moder & Rare \\
\hline
\end{tabular}

\begin{tabular}{|c|c|c|c|c|c|c|c|c|c|c|c|c|c|c|c|c|c|c|c|}
\hline \multirow[t]{2}{*}{ Station } & \multicolumn{19}{|c|}{$\begin{array}{c}\text { Mangrove density (trees/ha) } \\
\text { West Segara Anakan (station) }\end{array}$} \\
\hline & 23 & 24 & 25 & 26 & 27 & 28 & 29 & $\begin{array}{ll}30 & 31 \\
\end{array}$ & 32 & 33 & 34 & 35 & 36 & 37 & 38 & 39 & 40 & 41 & 42 \\
\hline Total & 166 & 767 & 833 & 400 & 500 & 600 & 2399 & 1233600 & 133 & 2133 & 1400 & 400 & 533 & 366 & 2000 & 333 & 500 & 3300 & 1499 \\
\hline $\mathrm{Sd}$ & 71 & 24 & 77 & 90 & 145 & 58 & 1328 & 118330 & 47 & 786 & 305 & 120 & 235 & 96 & 469 & 51 & 212 & 917 & 467 \\
\hline Class & Very rarely & Rare & Rare & Rare & Rare & Rare & High & Rare Rare & Rare & Moderate & Rare & Rare & Rare & Very rarely & yoderate & Very & y Rare & Very & h Rare \\
\hline
\end{tabular}

\begin{tabular}{lllllll}
\hline \multirow{2}{*}{ Station } & \multicolumn{5}{c}{$\begin{array}{c}\text { Mangrove density (trees/ha) } \\
\text { North Jakarta (station) }\end{array}$} \\
\cline { 2 - 7 } & 43 & 44 & 45 & 46 & 47 & 48 \\
\hline Total & 1100 & 311 & 330 & 220 & 600 & 738 \\
Sd & 255 & 32 & 66 & 54 & 113 & 278 \\
Class & Rare & Very rarely Very rarely Very rarely Rare & Rare \\
\hline
\end{tabular}


The other factor influences mangrove trees density is sedimentation. Essentially Sari et al. (2016) also noted higher sedimentation in West Segara Anakan and the East Segara Anakan from 26-103.60 gram day ${ }^{-1}$ and give a total deposit of around $0.22-8.05$ million tonnes year $^{-1}$. The potential sedimentation causes deposit accumulation which contributes to pore-water storage, clay mineral inflammation, low hydrodynamics, sediment deposition, and accretion landscape (Schwarzer et al. 2016; Hilmi 2018; Bomer et al. 2020; Hao Wang et al. 2020). Sari et al. (2016) and Hilmi et al. (2017) reported that the mangrove trees in Segara Anakan also caused accretion between 1.74$2.71 \mathrm{~cm}$ year $^{-1}$, because vegetation density plays a significant role in terms of capture and deposition. Suhendra et al. (2018) and Ross Jones et al. (2016) also explained that sedimentation is a trigger factor for mangrove trees growth, mangrove regeneration and mangrove adaptation The mangrove trees also are influenced by substrate and water quality factors. Meanwhile, the water quality and substrate showed the entire ecosystems with environmental qualities believed to support the mangrove trees development. The potential of substrate and water quality in Segara Anakan and North Coast of Jakarta can be shown in Table 3.

Table 3 showed that (i) soil nitrate is between 0.010$0.22 \%$, (ii) soil phosphate between $6.85-17.65 \%$, (iii) soil pyrite between $1.03-3.10 \%$, (iv) soil $\mathrm{pH}$ between 5.7-6.92, (v) soil salinity between 0-7.05, (vi) soil texture had clay, loam, loamy clay, mud, mud clay, (vii) water $\mathrm{pH}$ between 5.6-7.07, and (viii) water salinity between 0-40 ppt. These data match the Rachmawati (2019) report of West Segara Anakan, with potentials between 0.078-0.120 mg/L (phosphate), 25-36 ppt (salinity), 6.7-12.8 mg/L, 1.03$1.40 \%$ (pyrite), and muddy clay texture. Furthermore, Widowati (2018) data in East Segara Anakan include the range of 1.28-2.88\% (pyrite), 18-32.33 ppt (salinity), 19.77-28.91 mg/L (nitrate), 0.1083-0.192 mg/L (phosphate) and muddy clay texture. Based on (Shiau et al. 2017; Q. Yang et al. 2008), the potential for phosphate, nitrate, and fertility appeared moderate, while the $\mathrm{pH}$ was slightly acidic. Also, several studies completely showed the potentials for salinity, temperature, phosphate, and soil nitrate with great suitability for mangrove vegetation growth (Barreto et al. 2016; Hilmi, Sari, et al. 2019; Hilmi et al. 2017; Tam et al. 2009; Abdelhakeem, Aboulroos, and Kamel 2016), productivity of fine root and decomposition of organic carbon (Zhang et al. 2021). Consequently,
(Djohan 2012; Kusmana and Maulina 2015; Yin et al. 2018) stated the existence of mangrove ecosystems in brackish water, with the salinity ranging from 4-35 ppt (best range occurs from 10-30 ppt), and the optimum phosphate standard from $0.15-0.3 \mathrm{mg} / \mathrm{L}$ (Sharafatmandrad and Khosravi Mashizi 2020).

\section{Distribution of mangrove species density}

Distribution of mangrove species density is shown in Table 4 and Figure 3. The data in Table 4 and Figure 3 represents the density distribution of mangrove vegetation in Segara Anakan and the North Coast of Jakarta. The major species of mangrove vegetation showed a significant difference between these regions, while the density revealed the dominance level ( Huang et al. 2003; Hilmi et al. 2015, 2020; Khadim et al. 2019). Table 3 showed that in the research site were found Aegiceras corniculatum, Avicennia alba, Avicennia marina, Avicennia officinalis, Bruguiera gymnorrhiza, Bruguiera parviflora, Bruguiera sexangula, callophylum inophylum, Carbera manghas, Ceriops decandra, Ceriops, Rhizophora apiculata, Rhizophora mucronata, Rhizophora stylosa, Sonneratia alba, Sonneratia caseolaris, Tespia pulpunea, Terminalia cattapa, Xylocarpus granatum, and Xylocarpus moluccensis. According to Hilmi et al. (2015, 2017), Segara Anakan was comprised of several species ranging from Rhizophora apiculata, Rhizophora mucronata, Rhizophora stylosa, Bruguiera gymnorrhiza, Bruguiera parviflora, Bruguiera sexangula, Aegiceras corniculatum, Avicennia alba, Avicennia marina, Ceriops decandra, Ceriops tagal, Excoecaria agallocha, Heritiera littoralis, Nypa fruticans, Sonneratia alba, Sonneratia caseolaris, Xylocarpus granatum, and Xylocarpus moluccensis. Different from Table 4, Sreelekshmi et al. (2018) stated the occurrence of 18 mangrove types in Kerala, India, categorized into 5 groups. Group 1 was dominated by Rhizophora mucronate, $R$. apiculata, Ceriops tagal, Kandelia candel, Sonneratia alba, and S. caseolaris in the fringing zone. Group 2 and 3 were comprised of Avicennia marina, A. alba, Lumnitzera racemosa, Acrostichum aureum, Excoecaria agallocha, E. indica, Avicennia officinalis, Bruguiera gymnorrhiza, and Aegiceras corniculatum, in the intermediate region. Group 4 encompassed the Landward regions and is conquered by Bruguiera sexangula and B. cylindrica. Group 5 occurred in the widespread area with Acanthus ilicifolius.

Table 3. Environment characteristics of mangrove ecosystem

\begin{tabular}{|c|c|c|c|}
\hline \multirow{2}{*}{ Environment variables } & \multicolumn{2}{|c|}{ Segara Anakan of Cilacap } & \multirow[t]{2}{*}{ North Coast of Jakarta } \\
\hline & West & East & \\
\hline Soil nitrate $(\%)$ & $0.049-0.161$ & $0.095-0.22$ & $0.010-0.016$ \\
\hline Soil phosphate (\%) & $8.76-15.44$ & $6.85-17.65$ & $7.15-16.32$ \\
\hline Soil pyrite (\%) & $1.03-1.24$ & $1.60-2.88$ & $1.20-3.10$ \\
\hline Soil ph & $6.67-6.92$ & $5.91-6.25$ & $5.7-6.4$ \\
\hline Soil salinity (ppt) & $5.85-7.05$ & $5.21-7.01$ & $0-5$ \\
\hline Soil texture & Clay, loam, mud, mud clay & Clay, loam, mud, mud clay & Clay, loamy clay, mud clay \\
\hline Water ph & $5.85-7.05$ & $6.83-7.07$ & $5.6-6.9$ \\
\hline Water salinity (ppt) & $31-40$ & $18-31$ & $0-15$ \\
\hline Water temperature & $24-29$ & $26-30$ & $24-31$ \\
\hline
\end{tabular}


Table 4. Distribution of species density in mangrove ecosystem

\begin{tabular}{lcccc}
\hline \multirow{3}{*}{ Species } & \multicolumn{5}{c}{ Mangrove density (trees/ha) } \\
\cline { 2 - 5 } & \multicolumn{3}{c}{ Segara Anakan } & North Jakarta \\
\cline { 2 - 5 } & Average & Stdev & Average & Stdev \\
\hline Aegiceras corniculatum & 290 & 246 & & \\
Aegiceras floridum & 4 & 4 & & \\
Avicennia alba & 145 & 124 & & \\
Avicennia marina & 289 & 240 & 393 & 348 \\
Avicennia officinalis & 45 & 43 & & \\
Bruguiera gymnorryza & 143 & 126 & 20 & 14 \\
Bruguiera parviflora & 5 & 5 & & \\
Bruguiera sexangula & 36 & 35 & & \\
Calophyllum inophyllum & & & 11 & 1 \\
Cerbera manghas & & & 35 & 7 \\
Ceriops decandra & 64 & 60 & & \\
Ceriops tagal & 74 & 61 & & \\
Excoecaria agallocha & 18 & 19 & 90 & 40 \\
Heritiera littoralis & 8 & 9 & & \\
Nypa fruticans & 804 & 625 & 65 & 35 \\
Rhizophora apiculata & 227 & 186 & 35 & 7 \\
Rhizophora mucronata & 172 & 142 & 208 & 269 \\
Rhizophora stylosa & 346 & 291 & 228 & 288 \\
Sonneratia alba & 227 & 208 & & \\
Sonneratia caseolaris & 101 & 88 & 23 & 15 \\
Terminalia catappa & & & 73 & 29 \\
Thespesia populnea & & & 19 & 1 \\
Xyloracpus granatum & 92 & 86 & & \\
Xyloracpus muluccensis & 11 & 10 & & \\
\hline
\end{tabular}

Mangrove species density possibly influences species diversity, richness, uniformity (Arumugam et al. 2016; Azman et al. 2021) and plant structure (Sreelekshmi et al. 2018; Haitao et al. 2018; Wang et al. 2019) in addition to the adaptability to heavy metal pollution (Hilmi, Siregar, and Syakti 2017; Syakti et al. 2013), oil pollution (Syakti et al. 2013), sedimentation (Sari et al. 2016), salinity (Hilmi et al. 2020; Hilmi, Kusmana, et al. 2017; Win et al. 2019), texture, sea-level rise (Fu et al. 2018), and water quality (Bullock et al. 2017; Karl and Church 2017). The mangrove in Segara Anakan of Cilacap (SAL) and North Coast of Jakarta (NCJ) were dominated by major species like Rhizophora apiculate, Rhizophora mucronate, Rhizophora stylosa, Avicennia marina, and Nypa fruticans. The adaptation models of mangrove species in SAL and NCJ are related to the capacity to develop root systems, particularly in reducing erosion impact, sedimentation, nutrient cycling and pollution (Bullock et al. 2017; Yang et al. 2018). In mangrove ecosystem, the species density can represent the succession, geomorphology, external disturbances, ecophysiology, and competition (Bullock et al. 2017; Fu et al. 2018). Furthermore, species domination describes the adaptation of pioneer species, e.g Sonneratia spp and Avicennia spp, with dominant species, including Rhizophora spp., Bruguiea spp., Ceriops spp., and Nypa fruticans (Cooray et al. 2021; Fu et al. 2018).

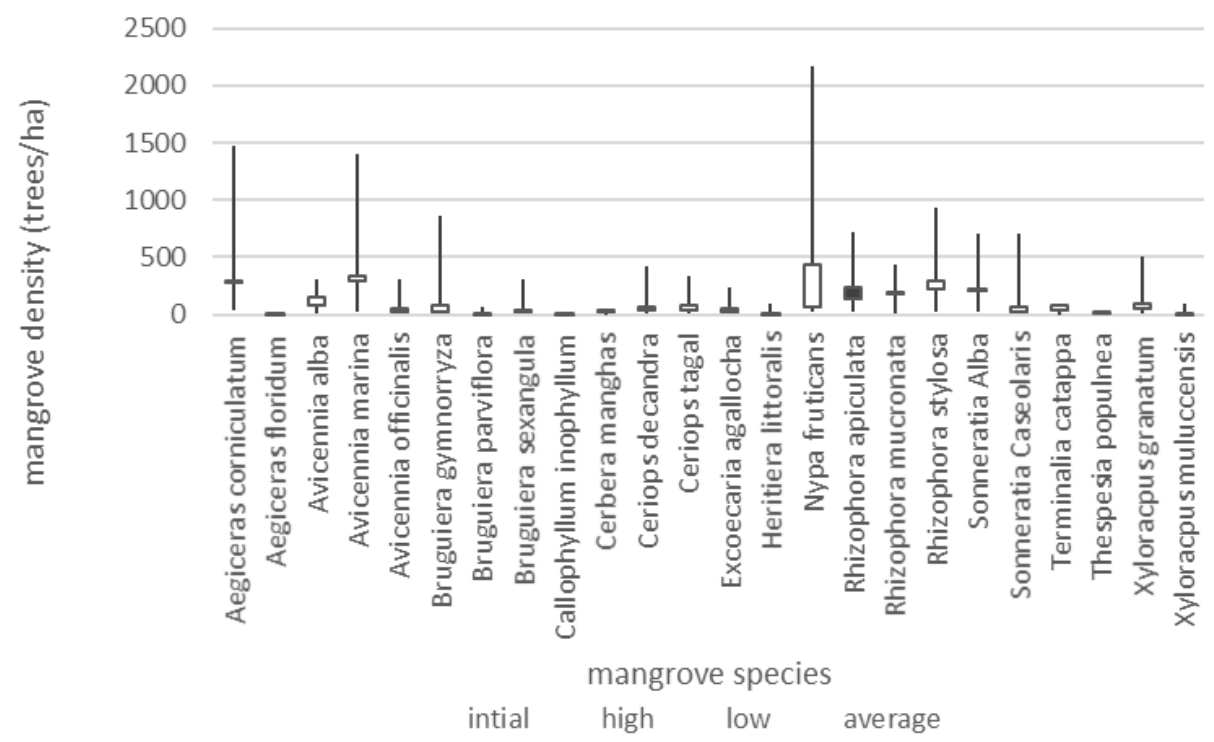

Distribution of mangrove species

\begin{tabular}{lrrrrlrrrr}
\hline Species & Intial & \multicolumn{1}{c}{ High } & Low & Average & Species & Intial & High & Low & Average \\
\hline Aegiceras corniculatum & 290 & 1,467 & 30 & 290 & Excoecaria agallocha & 18 & 233 & 5 & 54 \\
Aegiceras floridum & 4 & 10 & 0 & 4 & Heritiera littoralis & 8 & 100 & 0 & 8 \\
Avicennia alba & 73 & 300 & 15 & 145 & Nypa fruticans & 65 & 2167 & 20 & 434 \\
Avicennia marina & 289 & 1400 & 25 & 341 & Rhizophora apiculata & 235 & 725 & 20 & 131 \\
Avicennia officinalis & 22 & 300 & 5 & 45 & Rhizophora mucronata & 172 & 433 & 15 & 190 \\
Bruguiera gymnorryza & 20 & 867 & 10 & 82 & Rhizophora stylosa & 228 & 933 & 25 & 287 \\
Bruguiera parviflora & 3 & 67 & 0 & 5 & Sonneratia Alba & 227 & 700 & 20 & 227 \\
Bruguiera sexangula & 18 & 300 & 5 & 36 & Sonneratia Caseolaris & 23 & 700 & 5 & 62 \\
Callophyllum inophyllum & 5 & 11 & 0 & 11 & Terminalia catappa & 37 & 90 & 0 & 73 \\
Cerbera manghas & 18 & 40 & 0 & 35 & Thespesia populnea & 19 & 20 & 0 & 19 \\
Ceriops decandra & 32 & 420 & 10 & 64 & Xyloracpus granatum & 46 & 500 & 4 & 92 \\
Ceriops tagal & 37 & 333 & 10 & 74 & Xyloracpus muluccensis & 5 & 100 & 0 \\
\hline
\end{tabular}

Figure 3. Distribution of species in mangrove stations 
The dominant species in Segara Anakan include Nypa frutican, with an individual potential of $804 \pm 625$ trees/ha, while Rhizophora stylosa, Rhizophora apiculata, Aegiceras corniculatum, Soneratia alba, and Avicennia marina (moderate), with potential abundance ranging from 227-290 trees/ha and others are recessive species. Meanwhile, the North Coast of Jakarta is predominantly Avicennia marina, Rhizophora mucronata, and Rhizophora stylosa, with an abundance of 228n-393 trees/ha, and others are not widespread. Based on Hilmi et al. (2015), Avicennia spp. and Sonneratia spp. are common in West Segara Anakan, while Rhizophora apiculata, Nypa fruticans, and Aegiceras corniculatum reside extensively in the East. The species dominance gives indication has greatly adapted toward habitat conditions. For instance, Sonneratia alba and Avicennia spp. are very prevalent in regions with substrates and are directly in close water proximity (Avelar et al. 2017; Yin et al. 2018), Rhizophora spp. and Bruguiera spp. thrive in less flooded areas with relatively soft substrates (Hilmi et al. 2017). Meanwhile, Nypa fruticans dominance is due to the ability to replicate in groups with high density, specifically around river estuaries (Hilmi 2018). Leopold et al. (2013) also reported that the domination species have correlated with carbon absorption, oxygen, and nutrients from the soil and air and species relationship to develop a clustering pattern and species association (Pham et al. 2019). The species domination also influenced potential of root biomass, biomass productivity, density, and growth, the formation of stand structure and spatial distribution (Ahmad et al. 2016)

\section{The mangrove association}

The mangrove association shows a robust connection among the species and provides the framework for the analysis. Table 4 represents the association phenomenon in Segara Anakan. The mangrove association (positive, negative, and not associated) in North Coast of Jakarta and Segara Anakan are developed by three criteria that are (i) the avoidance of similar habitat, (ii) mutual basic biotic and abiotic environmental needs, (iii) one or more of these species are interconnected, either by attraction or rejection (Ludwig and Renold 1988). The positive and negative associations of mangrove species in Segara Anakan of Cilacap and Nort Coast Jakarta also described indicating the expectation of coexistence or mutual refusal to coexist.

The association of mangrove ecosystem in Table 4 showed (i) 12 pairs of negative associated, including $A$. alba-Ae.corniculatum, A. marina-Ae. corniculatum, A. marina-C. decandra, A. marina-C. tagal, A. marina $-N$. frutican, $B$. sexangula-X. granatum, $C$. decandra-N. fruticans, C. tagal-S. caseolaris, C. tagal-S. alba, N. fruticans-S. alba, A. alba-C. tagal, and A. alba-N. fruticans, (ii) 17 pairs of positively-associated mangrove vegetation, including A. marina-A. alba, A. marina-S. caseolaris, A. marina-S. alba, A. alba-S. caseolaris, A. alba-S. alba, B. parviflora-B. sexangula, B. parviflora-S. caseolaris, B. parviflora-S. alba, B. sexangula-S. alba, $C$. decandra-C. tagal, C. tagal-N. frutican, R. apiculata-R. mucronata, R. apiculata-R. stylosa, S. alba-B. sexangula, $S$. caseolaris-S. alba, S. caseolaris-B. sexangula, and E.
agallocha-X. granatum, (iii) most mangrove vegetation is not associated, almost reached positive or negative association. Most mangrove vegetations are not associated, indicating the tendency to form clusters among similar species. Kurniawan, Undaharta, and Pendit (2008) noted: (i) High-frequency pairs do not regularly produce positive associations; (ii) Pairs of types with low frequencies do not necessarily generate negative relations. Moreover, the data showed 2 association types in Segara Anakan, and are known to develop zonation or not show any correlation.

Positive association describes strong relationship between species in same habitat. Positive association also occurs when mangrove species have a collective relationship, or join other species because have similar needs (Kurniawan et al. 2008). As a consequence, a positively connected species tends to generate a definite spatial relationship with other kinds (Ludwig and Renold 1988). This condition shows a robust relationship of mangrove species with others varieties. Furthermore, two species with similar adaptions are constructed and presented in a grouping pattern. Previous studies described the association by presenting the adaptation between two species in mutual existence with similar habitat, due to related adjustment to associated environmental parameters, including sunlight, water, and soil (Hilmi et al. 2015)

Kairo et al. (2008), Petrakis et al. (2016), Khadim et al. (2019), and Azman et al. (2021) clarified the species pairs do not constantly produce positive relationships. Moreover, plant groups with high occurrence, are not commonly generating extensive positive association. In similar conditions, low presence does not repeatedly demonstrate a negative correlation with other species. Negative association shows no tolerance for coexisting in related ecosystem or have no mutually beneficial relationships. Essentially, the survival of several species in the community instigates the possibility of competition and development of species compositions or clusters. In the mangrove ecosystem, the cluster is shown as a mangrove zoning to illustrate the connection between several mangrove types (Hilmi et al. 2015, 2017).

Potential mangrove associations are influenced by the relationships among species, pollution and human activities (Pham et al. 2019). For instance, the decline in Avicennia alba-Sonneratia alba (Association I) by $20.1 \%$ and an increase of Rhizophora apiculata (Association II) by $34.7 \%$ were caused by aquaculture and other human activities (Pham et al. 2019). Other factors are potential of soil carbon sequestration (Chen et al. 2021) and human activity causes degradation of nutrients and microorganisms, sedimentation and logging (Sun et al. 2020).

Furthermore, mangrove association and ecosystem potential tend to influence the habitat, biodiversity, and potential wildlife fauna. These situations further impacted on buffer zones of retaining nutrients ( $\mathrm{Li}$ et al. 2016; Hao Wang et al. 2020) and also provided the spawning habitat, nursery ground habitat, and feeding base for several faunas (Nagelkerken et al. 2008; Jones et al. 2015; Abdelhakeem et al. 2016). 
Table 4. The mangrove Asosiation in Segara Anakan of Cilacap

\begin{tabular}{|c|c|c|c|}
\hline Vegetation relationship & Chi-square & $\mathbf{E}(\mathbf{A})$ & Association \\
\hline $\begin{array}{l}\text { A. alba-Ae.corniculatum, A. marina-Ae. Corniculatum, A. marina-C. decandra, A. marina-C. tagal, A. marina-N. frutican, B. sexangula-X. granatum, } \\
\text { C. decandra-N. frutican, C. tagal-S. caseolaris, C. tagal-S. alba, N. frutican-S. alba, A. alba-C. tagal, A. alba-N. fruticans }\end{array}$ & $4.02-11.81$ & $1.82-8.73$ & Negative \\
\hline $\begin{array}{l}\text { A. marina-A. alba, A. marina-S. caseolaris, A. marina-S. alba, A. alba-S. caseolaris, A. alba-S. alba, B. parviflora-B. sexangula, B. parviflora-S. } \\
\text { caseolaris, B. parviflora-S. alba, B. sexangula-S. alba, C. decandra-C. tagal, C. tagal-N. frutican, R. apiculata-R. mucronata, R. apiculata-R. stylosa, } \\
\text { S. alba-B. sexangula, S. caseolaris-S. alba, S. caseolaris-B. sexangula, E. agallocha-X. granatum }\end{array}$ & $4.07-18.16$ & $0.09-12.09$ & Positive \\
\hline $\begin{array}{l}\text { Ae. corniculatum-A. lanata, Ae. corniculatum-A. officianalis, Ae. corniculatum-B. gymnorrhiza, Ae. corniculatum-B. parviflora, Ae. corniculatum-B. } \\
\text { sexangula, Ae. corniculatum-C. decandra, Ae. corniculatum- } R \text {. apiculata, Ae. corniculatum- } R . \text { mucronata, Ae. corniculatum- } R . \text { stylosa, Ae. } \\
\text { corniculatum-S. caseolaris, Ae. corniculatum-L. Racemosa, Ae. corniculatum-E. agallocha, Ae. corniculatum-X. granatum, A. alba-A. lanata, A. } \\
\text { alba-A. officianalis, A. alba-B. gymnorrhiza }\end{array}$ & $0.03-2.92$ & $0.06-2.33$ & Not associated \\
\hline \multicolumn{4}{|l|}{$\begin{array}{l}\text { A. alba-B. parviflora, A. alba-B. sexangula, A. alba-C. decandra, A. alba-C. tagal, A. alba- } N \text {. frutican, A. alba-R. apiculata, A. alba-R. mucronata, A. } \\
\text { alba-R. stylosa, A. alba-L. Racemosa, A. alba-E. agallocha, A. alba-X. granatum, A. lanata-A. officianalis, A. lanata-B. gymnorrhiza, A. lanata-B. } \\
\text { parviflora, A. lanata-B. sexangula, A. lanata-C. decandra, A. lanata-C. tagal, A. lanata-R. apiculata, A. lanata-R. mucronata, A. lanata-R. stylosa, A. } \\
\text { lanata-L. Racemosa, A. lanata-E. agallocha, A. lanata-X. granatum, A. marina-A. officianalis, A. marina-B. gymnorrhiza, A. marina-B. parviflora, A. } \\
\text { marina-B. sexangula, A. marina-R. mucronata, A. marina-R. stylosa, A. marina-L. Racemosa, A. marina-E. agallocha }\end{array}$} \\
\hline \multicolumn{4}{|l|}{ 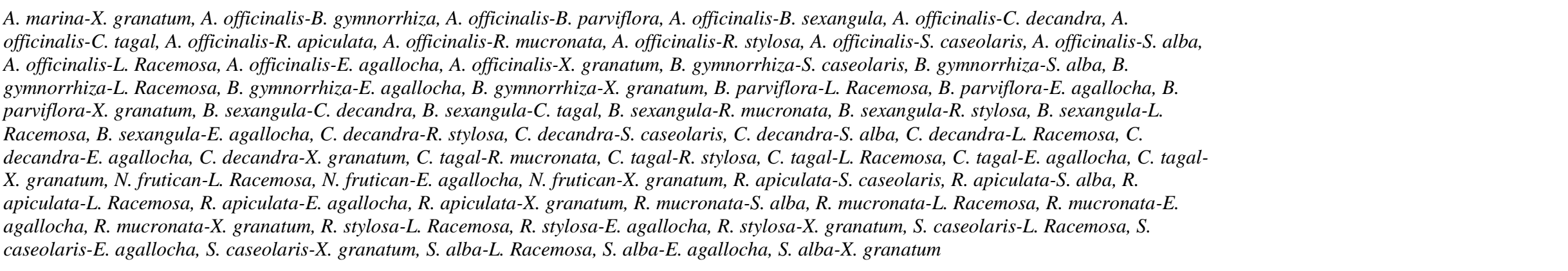 } \\
\hline 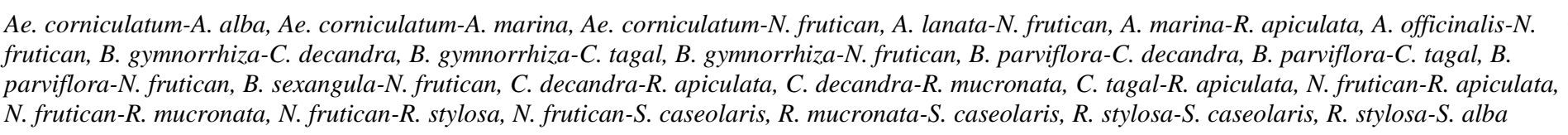 & $0.03-11.81$ & $0.06-8.73$ & $\begin{array}{l}\text { Not associated to } \\
\text { negative } \\
\text { association }\end{array}$ \\
\hline $\begin{array}{l}\text { Ae. corniculatum-S. alba, A. alba-A. marina, Ae. corniculatum-C. tagal, A. alba-S. caseolaris, A. alba-S. alba, A. lanata-A. marina, A. lanata-S. } \\
\text { caseolaris, A. lanata-S. alba, A. marina-S. alba, B. gymnorrhiza-B. parviflora, B. gymnorrhiza-B. sexangula, B. gymnorrhiza-R. apiculata, B. } \\
\text { gymnorrhiza-R. mucronata, B. gymnorrhiza-R. stylosa, B. parviflora-R. apiculata, B. parviflora-R. mucronata, B. parviflora-R. stylosa, B. sexangula- } \\
R . \text { apiculata, B. sexangula-S. caseolaris, } R . \text { mucronata-R. stylosa, L. racemosa-E. agallocha, L. racemosa-X. granatum }\end{array}$ & $0.03-18.16$ & $0.06-12.09$ & $\begin{array}{l}\text { Not associated to } \\
\text { positive } \\
\text { association }\end{array}$ \\
\hline
\end{tabular}




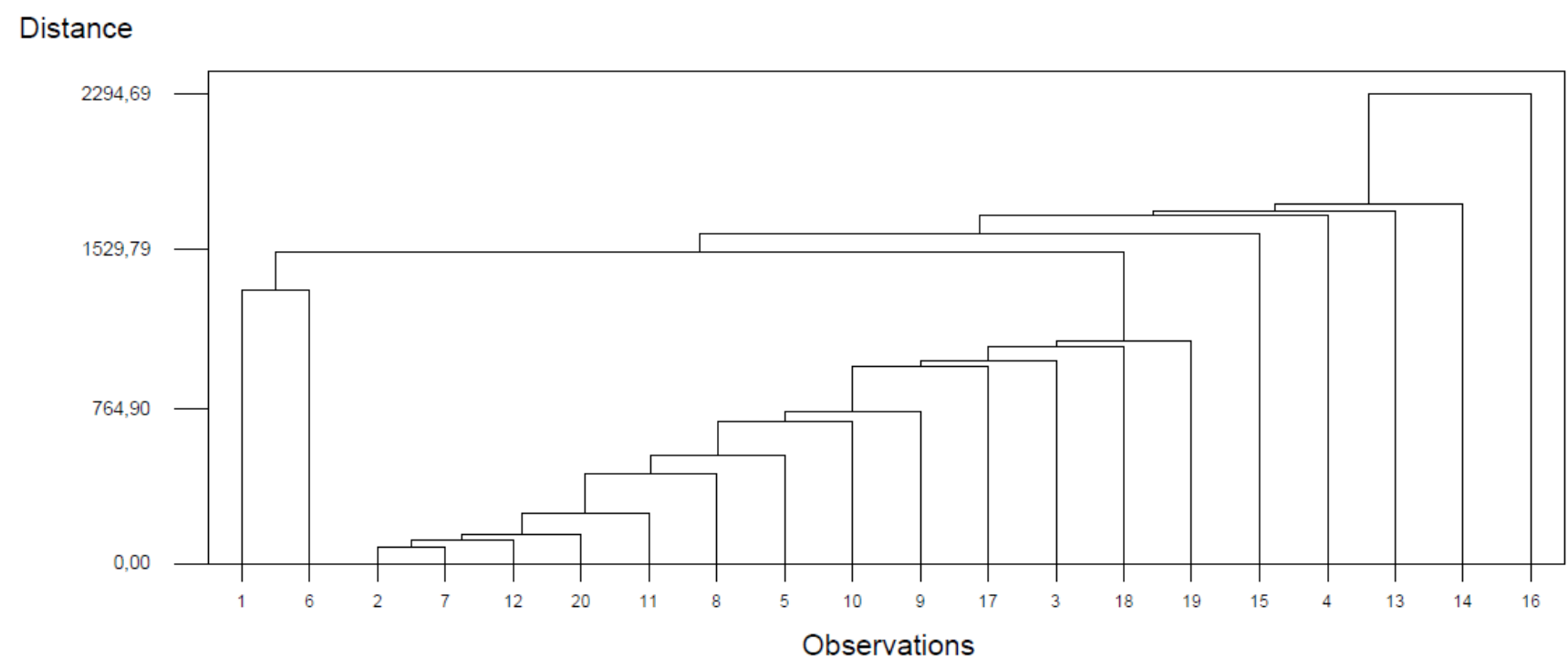

Figure 4. Dendogram of species cluster in mangrove ecosystem Segara Anakan, Cilacap, Indonesia. Note: 1. Aegiceras corniculatum, 2. Aegiceras floridum, 3. Avicennia alba, 4. Avicennia marina, 5. Avicennia officinalis, 6. Bruguiera gymnorrhiza, 7. Bruguiera parviflora, 8. Bruguiera sexangula, 9. Ceriops decandra, 10. Ceriops tagal, 11. Excoecaria agallocha, 12. Heritiera littoralis, 13. Nypa frutican, 14. Rhizophora apiculata, 15. Rhizophora mucronata, 16. Rhizophora stylosa, 17. Sonneratia alba, 18. Sonneratia caseolaris, 19. Xylocarpus granatum, 20. Xylocarpus moluccensis.

Table 5. Clustering of mangrove species

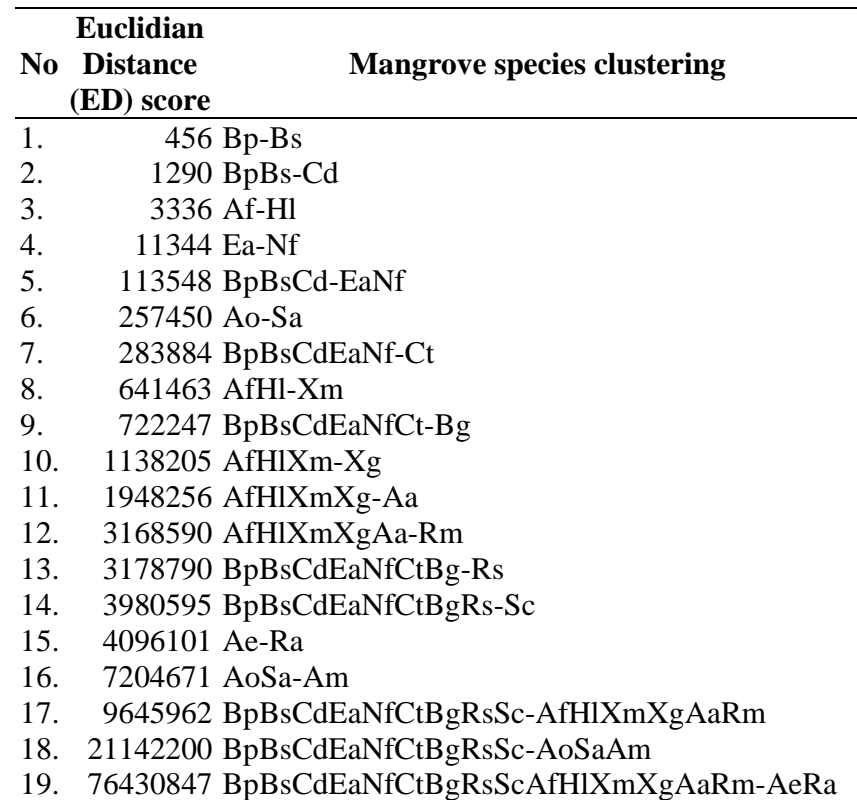

Note: Ac: Aegiceras corniculatum, Ae: Aegiceras floridum, Aa: Avicennia alba, Am: Avicennia marina, Ao: Avicennia officinalis, $\mathrm{Bg}$ : Bruguiera gymnorryza, Bp: Bruguiera parviflora, Bs: Bruguiera sexangular, $\mathrm{Ci}$ : Callophyllum inophyllum, $\mathrm{Cm}$ : Cerbera manghas, Cd: Ceriops decandra, Ct: Ceriops tagal, Ea: Excoecaria agallocha, Hl: Heritiera littoralis, Nf: Nypa fruticans, Ra: Rhizophora apiculate, Rm: Rhizophora mucronata, Rs: Rhizophora stylosa, Sa: Sonneratia alba, Sc: Sonneratia caseolaris, Tc: Terminalia catappa, Tp: Thespesia populnea, Xg: Xyloracpus granatum, Xm: Xyloracpus muluccensis

\section{Cluster of mangrove density}

The cluster of mangrove density can be shown in Table 5 and Figure 4. The data in Table 5 and Figure 4 showed the cluster of mangrove density in West and East Segara Anakan, Cilacap. This arrangement follows the dissimilarity pattern, as illustrated by the Euclidian distance index (Ludwig and Renold, 1988).

Based on the potential mangrove density at each station in Segara Anakan, 3 primary clusters with ED values between 254-3,498, were created (Rachmawati 2019) and also structured, due to the dominance of Avicennia marina, Avicennia alba, Rhizophora apiculate, Rhizophora stylosa, Rhizophora mucronate, and Sonneratia caseolaris, and Nypa fruticans. Also, East Segara Anakan showed 3 clusters with potential ED between 512.8-4,580.2, with the common types of Avicennia marina, Avicennia alba, Rhizophora apiculata, Rhizophora mucronata, Rhizophora stylosa, and Sonneratia alba (D Widowati 2018).

Cluster analysis in Segara Anakan, Cilacap and North Coast of Jakarta indicate a pattern of species grouping and kinship in reducing environmental impact factors, including sedimentation (Sari et al. 2016; Bullock et al. 2017; Bomer et al. 2020), tides (Bomer et al. 2020), hydrodynamic oceanography (Bomer et al. 2020), water logging (Fu et al. 2018), soil stability (Fu et al. 2018), carbon, $\mathrm{CO}_{2}$ and organic matter (Leopold et al. 2013), natural disasters (Hilmi 2018; Win et al. 2019) as well as other environmental factors, including salinity, $\mathrm{pH}$ and soil fertility (Ahmed et al. 2021). The adaptation was reflected in the presence of root patterns, biomass potential (Ahmed et al. 2021), nutrient absorption (Pham et al. 2019), nutrient decomposition (Leopold et al. 2013), and the ability to trap sediment and nutrients (Fu et al. 2018). These abilities and adaptation circumstances 
have significantly impacted the formation of species clusters, association pattern, structure, vertical and horizontal distribution, biodiversity, as well as zoning (Hilmi et al. 2015; Arumugam et al. 2016; Hilmi 2018; Sreelekshmi et al. 2018; Win et al. 2019).

In conclusion, the potential mangrove density in East and West Segara Anakan occur between 166-4,000 trees $\mathrm{ha}^{-1}$ and 133-3,000 trees ha ${ }^{-1}$, respectively, while the North Coast of Jakarta ranged from 220-1,100 trees ha ${ }^{-1}$. As a consequence, the predominant species in Segara Anakan were Nypa fruticans (high dominant), Rhizophora stylosa, Rhizophora apiculata, Aegiceras corniculatum, Soneratia alba and Avicennia marina (moderate). Meanwhile, the North Coast of Jakarta was mostly occupied by Avicennia marina, Rhizophora mucronata and Rhizophora stylosa. The mangrove ecosystem generated 12 and 17 species pairs, with negative and positive association, respectively. However, most sets were neutral, indicating the tendency to form groups, based on species similarity or zoning. Furthermore, the cluster analysis showed the formation of 4 mangrove clusters, with the closest unit as Bruguiera parviflora-Bruguiera sexangula.

\section{ACKNOWLEDGEMENTS}

We would like to thank Dr. Isdy Sulystio (Dean of the Faculty of Fisheries and Marine Science, Universitas Jenderal Soedirman (Unsoed), Indonesia), LPPM Unsoed to support grant with Riset Unggulan (2021) and researcher colleague for providing his advice for this research. We would also like to thank anonymous reviewers for their helpful and constructive comments which greatly helped us improve our manuscript.

\section{REFERENCES}

Abdelhakeem SG, Aboulroos SA, Kamel MM. 2016. Performance of a vertical subsurface flow constructed wetland under different operational conditions. J Adv Res 7 (5): 803-814. DOI: 10.1016/j.jare.2015.12.002

Ahmad CB, Abdullah J, Jaafar J. 2016. Buffer Zone Delineation at Conservation Reserve. Procedia Soc Behav Sci 222: 685-692. DOI: 10.1016/j.sbspro.2016.05.227.

Ahmed S, Kamruzzaman M, Azad MS, Khan MNI. 2021. Fine root biomass and its contribution to the mangrove communities in three saline zones of Sundarbans, Bangladesh. Rhizosphere 100294. DOI: 10.1016/j.rhisph.2020.100294.

Arumugam S, Sigamani S, Samikannu M, Perumal M. 2016. Assemblages of phytoplankton diversity in different zonation of Muthupet mangroves. Reg Stud Mar Sci 3: 234-241. DOI: 10.1016/j.rsma.2015.11.005.

Avelar S, van der Voort TS, Eglinton TI. 2017. Relevance of carbon stocks of marine sediments for national greenhouse gas inventories of maritime nations. Carbon Balance Manag 12: 10. DOI: 10.1186/s13021-017-0077-x.

Azman MS, Sharma S, Shaharudin MAM, Hamzah ML, Adibah SN, Zakaria RM, MacKenzie RA. 2021. Stand structure, biomass and dynamics of naturally regenerated and restored mangroves in Malaysia. For Ecol Manag 482: 118852. DOI: 10.1016/j.foreco.2020.118852.

Barreto MB, Lo Mónaco S, Díaz R, Barreto-Pittol E, López L, Peralba M, do CR. 2016. Soil organic carbon of mangrove forests (Rhizophora and Avicennia) of the Venezuelan Caribbean coast. Organic Geochem 100: 51-61. DOI: 10.1016/j.orggeochem.2016.08.002
Bomer EJ, Wilson CA, Hale RP, Hossain ANM, Rahman FMA. 2020. Surface elevation and sedimentation dynamics in the GangesBrahmaputra tidal delta plain, Bangladesh: Evidence for mangrove adaptation to human-induced tidal amplification. Catena 187: 104312. DOI: 10.1016/j.catena.2019.104312.

Bullock EL, Fagherazzi S, Nardin W, Vo-Luong P, Nguyen P, Woodcock CE. 2017. Temporal patterns in species zonation in a mangrove forest in the Mekong Delta, Vietnam, using a time series of Landsat imagery. Cont Shelf Res 147: 144-154. DOI: 10.1016/j.csr.2017.07.007.

Castillo JAA, Apan AA, Maraseni TN, Salmo SG. 2017. Soil C quantities of mangrove forests, their competing land uses, and their spatial distribution in the coast of Honda Bay, Philippines. Geoderma 293: 82-90. DOI: 10.1016/j.geoderma.2017.01.025.

Chen S, Chen B, Chen G, Ji J, Yu W, Liao J, Chen G. 2021. Higher soil organic carbon sequestration potential at a rehabilitated mangrove comprised of Aegiceras corniculatum compared to Kandelia obovata. Sci Total Environ 752: 142279. DOI: 10.1016/j.scitotenv.2020.142279.

Cochard R, Ranamukhaarachchi SL, Shivakoti GP, Shipin OV, Edwards PJ, Seeland KT. 2008. The 2004 tsunami in Aceh and Southern Thailand: A review on coastal ecosystems, wave hazards and vulnerability. Perspect Plant Ecol Evol Syst 10 (1): 3-40. DOI: 10.1016/j.ppees.2007.11.001.

Cooray PLIGM, Jayawardana DT, Gunathilake BM, Pupulewatte PGH. 2021. Characteristics of tropical mangrove soils and relationships with forest structural attributes in the northern coast of Sri Lanka. Reg Stud Mar Sci 44: 101741. DOI: 10.1016/j.rsma.2021.101741.

Dencer-Brown AM, Alfaro AC, Bourgeois, C., Sharma, S., Milne, S. 2020. The secret lives of mangroves: Exploring New Zealand's urban mangroves with integrated biodiversity assessments. Ocean Coast Manag 191: 105185. DOI: 10.1016/J.OCECOAMAN.2020.105185.

Djohan TS. 2012. The disturbed ecosystem of Segara Anakan, Central Java. J Manusia dan Lingkungan 19 (3): 294-302.

Fu H, Wang W, Ma W, Wang M. 2018. Differential in surface elevation change across mangrove forests in the intertidal zone. Estuar Coast Shelf Sci 207: 203-208. DOI: 10.1016/j.ecss.2018.03.025.

Giri C, Long J, Abbas S, Murali RM, Qamer FM, Pengra B, Thau D. 2015. Distribution and dynamics of mangrove forests of South Asia. J Environ Manag 148: 101-111. DOI: 10.1016/j.jenvman.2014.01.020.

Hidayati NV, Hilmi E, Haris A, Effendi H, Guiliano M, Doumenq P, Syakti AD. 2011. Fluorene removal by biosurfactants producing Bacillus megaterium. Waste Biomass Valor 2 (4): 415-422. DOI: 10.1007/s12649-011-9085-3.

Hilmi E. 2018. Mangrove landscaping using the modulus of elasticity and rupture properties to reduce coastal disaster risk. Ocean Coastal Manag 165: 71-79. DOI: 10.1016/j.ocecoaman.2018.08.002.

Hilmi E, Kusmana C, Suhendang E, Iskandar. 2017. Correlation analysis between seawater intrusion and mangrove greenbelt. Indon J For Res 4 (2): 151-168. DOI: 10.20886/ijfr.2017.4.2.151-168.

Hilmi E, Kusmana C, Suhendang E, Iskandar. 2019. The carbon conservation of mangrove ecosystem in Indonesia. Biotropia 26 (3): 1-16. DOI: 10.11598/btb.2019.26.3.1099.

Hilmi E, Pareng R, Vikaliana R, Kusmana C, Iskandar Sari LK, Setijanto. 2017. The carbon conservation of mangrove ecosystem applied REDD program. Reg Stud Mar Sci 16: 152-161. DOI: 10.1016/j.rsma.2017.08.005.

Hilmi E, Sari LK, Amron. 2020. Distribusi Sebaran Mangrove Dan Faktor Lingkungan Pada Ekosistem Mangrove Segara Anakan Lagoon, Cilacap. Prosiding Seminar Nasional "Pengembangan Sumber Daya Perdesaan Dan Kearifan Lokal Berkelanjutan IX" 19-20 November 2019. [Indonesia]

Hilmi E, Sari LK, Cahyo TN, Kusmana C, Suhendang E. 2019. Carbon sequestration of mangrove eosystem in Segara Anakan Lagoon, Cilacap, Indonesia. Biotropia 26 (3): 181-190. DOI: 10.11598/btb.2019.26.3.1099.

Hilmi E, Siregar AS, Febryanni L. 2015. Struktur komunitas, zonasi dan keanekaragaman hayati vegetasi mangrove di Segara Anakan, Cilacap. Omni-Akuatika $11 \quad$ (2): 20-32. DOI: 10.20884/1.oa.2015.11.2.36. [Indonesian]

Hilmi E, Siregar AS, Syakti AD. 2017. Lead $(\mathrm{Pb})$ distribution on soil, water and mangrove vegetation matrices in Eastern Part of Segara Anakan, Cilacap. Omni-Akuatika 13 (2): 25-38. DOI: 10.20884/1.oa.2017.13.2.83. [Indonesian]

Huang L, Tan Y, Song X, Huang X, Wang H, Zhang S, Dong J, Chen R. 2003. The status of the ecological environment and a proposed protection strategy in Sanya Bay, Hainan Island, China. Marine 
Pollution Bulletin 47 (1-6): 180-186. DOI: 10.1016/S0025 326X(03)00070-5.

Jones R, Ricardo GF, Negri AP. 2015. Effects of sediments on the reproductive cycle of corals. Mar Pollut Bull 100 (1): 13-33. DOI: 10.1016/j.marpolbul.2015.08.021.

Jones, Ross, Bessell-Browne P, Fisher R, Klonowski W, Slivkoff M. 2016. Assessing the impacts of sediments from dredging on corals. Mar Pollut Bull 102 (1): 9-29. DOI: 10.1016/j.marpolbul.2015.10.049

Joshi K, Bhatt D. 2015. Avian species distribution along elevation at Doon Valley (foothills of western Himalayas), Uttarakhand, and its association with vegetation structure. J Asia-Pac Biodiv 8 (2): 158167. DOI: $10.1016 /$ j.japb.2015.04.002.

Kairo JG, Lang'at JKS, Dahdouh-Guebas F, Bosire J, Karachi M. 2008. Structural development and productivity of replanted mangrove plantations in Kenya. For Ecol Manag 255 (7): 2670-2677. DOI: 10.1016/j.foreco.2008.01.031.

Karl DM, Church MJ. 2017. Ecosystem structure and dynamics in the north pacific subtropical Gyre: New views of an old ocean. Ecosystems 20 (3): 433-457. DOI: 10.1007/s10021-017-0117-0.

Khadim FK, Su H, Xu L, Tian J. 2019. Soil salinity mapping in Everglades National Park using remote sensing techniques and vegetation salt tolerance. Phys Chem Earth 110: 31-50. DOI: 10.1016/j.pce.2019.01.004.

Kurniawan A, Undaharta NKE, Pendit IMR. 2008. Association of dominated tree species in lowland tropical forest of Tangkoko Nature Reserve, Bitung, North Sulawesi. Biodiversitas 9 (3): 199-203. DOI: 10.13057/biodiv/d090310.

Kusmana C, Maulina S. 2015. The growth responses of bakau (Rhizophora mucronata Lamk.) seedling on various inundations of level and duration. Jurnal Silvikultur Tropika 5 (3): 155-159. [Indonesian]

Leng B, Cao KF. 2020. The sap flow of six tree species and stand water use of a mangrove forest in Hainan, China. Global Ecol Conserv 24: e01233. DOI: 10.1016/j.gecco.2020.e01233.

Leopold A, Marchand C, Deborde J, Chaduteau C, Allenbach M. 2013 Influence of mangrove zonation on $\mathrm{CO} 2$ fluxes at the sediment-air interface (New Caledonia). Geoderma 202-203: 62-70. DOI: 10.1016/j.geoderma.2013.03.008

Li R, Chai M, Guo M, Qiu G. Y. 2016. Sediment accumulation and mercury ( $\mathrm{Hg}$ ) flux in Avicennia marina forest of Deep Bay, China Estuar Coast Shelf Sci 177: 41-46. DOI: 10.1016/J.ECSS.2016.05.005.

Ludwig J, Renold J. 1988. Statistical Ecology (A Primer on Methods and Computing). John Wiley and Sons, New York.

Nagelkerken I, Blaber SJM, Bouillon S, Green P, Haywood M, Kirton LG, Meynecke JO, Pawlik J, Penrose HM, Sasekumar A, Somerfield PJ. 2008. The habitat function of mangroves for terrestrial and marine fauna: A review. Aquat Bot 89 (2): 155-185. DOI: 10.1016/j.aquabot.2007.12.007.

Njana MA. 2020. Structure, growth, and sustainability of mangrove forests of mainland Tanzania. Global Ecol Conserv 2020: e01394. DOI: 10.1016/j.gecco.2020.e01394.

Orchard SE, Stringer LC, Quinn CH. 2015. Impacts of aquaculture on social networks in the mangrove systems of northern Vietnam. Ocean Coast Manag 114: 1-10. DOI: 10.1016/j.ocecoaman.2015.05.019.

Owuor MA, Mulwa R, Otieno P, Icely J, Newton A. 2019. Valuing mangrove biodiversity and ecosystem services: A deliberative choice experiment in Mida Creek, Kenya. Ecosyst Serv 2019: 101040. DOI: 10.1016/j.ecoser.2019.101040.

Petrakis R, Wu Z, McVay J, Middleton B, Dye D, Vogel J. 2016. Vegetative response to water availability on the San Carlos Apache Reservation. For Ecol Manag 378: 14-23. DOI: 10.1016/j.foreco.2016.07.012.

Pham LTH, Vo TQ, Dang TD, Nguyen UTN. 2019. Monitoring mangrove association changes in the Can Gio biosphere reserve and implications for management. Remote Sens Appl Soc Environ 13 298-305. DOI: 10.1016/j.rsase.2018.11.009.

Rachmawati A. 2019. Clustering Mangrove Berdasarkan Tingkat Kerapatan Di Segara Anakan Bagian Barat, Cilacap. Universitas Jenderal Soedirman, Banyumas. [Indonesian]

Rougier C, Pourriot R, Lam-Hoai T, Guiral D. 2005. Ecological patterns of the rotifer communities in the Kaw River estuary (French Guiana). Estuar Coast Shelf Sci 63 (1-2): 83-91. DOI: 10.1016/j.ecss.2004.08.023.

Sari LK, Adrianto L, Soewardi K, Atmadipoera AS, Hilmi E. 2016. Sedimentation in lagoon waters (Case study on Segara Anakan Lagoon, Cilacap). AIP Conf Proc 1730: 4947417. DOI 10.1063/1.4947417.
Schwarzer K, Thanh NC, Ricklefs K. 2016. Sediment re-deposition in the mangrove environment of Can Gio, Saigon River estuary (Vietnam). J Coast Res 75 (supp1): 138-142. DOI: 10.2112/si75-028.1

Sharafatmandrad M, Khosravi MA. 2020. Investigating distribution of ecosystem services in rangeland landscapes: an approach based on weighted key functional traits. Ecol Indicat 111: 105971. DOI: 10.1016/j.ecolind.2019.105971.

Shiau YJ, Lee SC, Chen TH, Tian G, Chiu CY. 2017. Water salinity effects on growth and nitrogen assimilation rate of mangrove (Kandelia candel) seedlings. Aquat Bot 137: 50-55. DOI: 10.1016/j.aquabot.2016.11.008

Sreelekshmi S, Preethy CM, Varghese R, Joseph P, Asha CV, Bijoy Nandan S, Radhakrishnan CK. 2018. Diversity, stand structure, and zonation pattern of mangroves in southwest coast of India. J Asia-Pac Biodiv 11 (4): 573-582. DOI: 10.1016/j.japb.2018.08.001.

Suhendra, Amron A, Hilmi E. 2018. The pattern of coastline change based on the characteristics of sediment and coastal slope in Pangenan coast of Cirebon, West Java. E3S Web Conf 47: 06001. DOI: 10.1051/e3sconf/20184706001.

Sun H, He Z, Zhang M, Yen L, Cao Y, Hu Z, Peng Y, Lee SY. 2020. Spatial variation of soil properties impacted by aquaculture effluent in a small-scale mangrove. Mar Pollut Bull 160: 111511. DOI: 10.1016/j.marpolbul.2020.111511.

Syakti AD, Ahmed MM, Hidayati NV, Hilmi E, Sulystyo I, Piram A, Doumenq P. 2013. Screening of emerging pollutants in the mangrove of Segara Anakan Nature Reserve, Indonesia. IERI Procedia 5: 216222. DOI: 10.1016/j.ieri.2013.11.095.

Syakti AD, Hidayati NV, Hilmi E, Piram A, Doumenq P. 2013. Source apportionment of sedimentary hydrocarbons in the Segara Anakan Nature Reserve, Indonesia. Mar Pollut Bull 74 (1): 141-148. DOI: 10.1016/j.marpolbul.2013.07.015.

Tam NFY, Wong AHY, Wong MH, Wong YS. 2009. Mass balance of nitrogen in constructed mangrove wetlands receiving ammonium-rich wastewater: Effects of tidal regime and carbon supply. Ecol Eng 35 (4): 453-462. DOI: $10.1016 /$ j.ecoleng.2008.05.011

Wang, Haitao, Gilbert JA, Zhu Y, Yang X. 2018. Salinity is a key factor driving the nitrogen cycling in the mangrove sediment. Sci Total Environ 631-632: 1342-1349. DOI: 10.1016/j.scitotenv.2018.03.102.

Wang, Hao, Liu G, Li Z, Zhang L, Wang Z. 2020. Processes and driving forces for changing vegetation ecosystem services: Insights from the Shaanxi Province of China. Ecol Indicat 112: 106105. DOI: 10.1016/j.ecolind.2020.106105.

Wang Y, Ying H, Yin Y, Zheng H, Cui Z. 2019. Estimating soil nitrate leaching of nitrogen fertilizer from global meta-analysis. Sci Total Environ 657: 96-102. DOI: 10.1016/j.scitotenv.2018.12.029

Widowati D. 2018. Clustering Vegetasi Mangrove Di Segara Anakan Bagian Timur, Cilacap. Universitas Jenderal Soedirman, Banyumas. [Indonesian]

Win S, Towprayoon S, Chidthaisong A. 2019. Adaptation of mangrove trees to different salinity areas in the Ayeyarwaddy Delta Coastal Zone, Myanmar. Estuar Coast Shelf Sci 228: 106389. DOI: 10.1016/j.ecss.2019.106389.

Xiong J, Mei X, Liu J. 2003. Comparative studies on community structure, biodiversity of plankton and zoobenthos in four lakes of different trophic states in China. Water 16: 361-372.

Xiong Y, Liao B, Proffitt E, Guan W, Sun Y, Wang F, Liu X. 2018. Soil carbon storage in mangroves is primarily controlled by soil properties: A study at Dongzhai Bay, China. Sci Total Environ 619620: 1226-1235. DOI: 10.1016/j.scitotenv.2017.11.187.

Yang Q, Tam NFY, Wong YS, Luan TG, Su WS, Lan CY, Shin PKS, Cheung SG. 2008. Potential use of mangroves as constructed wetland for municipal sewage treatment in Futian, Shenzhen, China. Mar Poll Bull 57 (6-12): 735-743. DOI: 10.1016/j.marpolbul.2008.01.037.

Yang Z, Song W, Zhao Y, Zhou J, Wang Z, Luo Y, Li Y, Lin G. 2018. Differential responses of litter decomposition to regional excessive nitrogen input and global warming between two mangrove species. Estuar Coast Shelf Sci 214: 141-148. DOI: 10.1016/j.ecss.2018.09.018.

Yin P, Yin M, Cai Z, Wu G, Lin G, Zhou J. 2018. Structural inflexibility of the rhizosphere microbiome in mangrove plant Kandelia obovata under elevated $\mathrm{CO}_{2}$. Mar Environ Res 140: 422-432. DOI: 10.1016/j.marenvres.2018.07.013.

Zhang Y, Xiao L, Guan D, Chen Y, Motelica-Heino M, Peng Y, Lee SY. 2021. The role of mangrove fine root production and decomposition on soil organic carbon component ratios. Ecol Indicat 125: 107525. DOI: 10.1016/j.ecolind.2021.107525. 